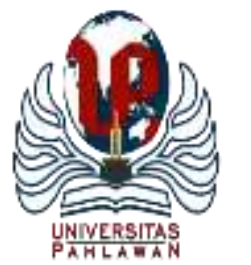

Edukatif : Jurnal Ilmu Pendidikan Volume 4 Nomor 1 Tahun 2022 Halm 227 - 232

EDUKATIF: JURNAL ILMU PENDIDIKAN

Research \& Learning in Education

https://edukatif.org/index.php/edukatif/index

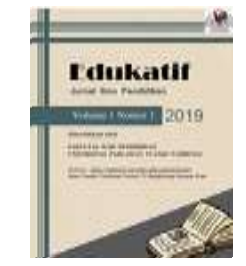

\title{
Enhancing Student's Vocabulary by Using Flashcard Media Via Google Classroom During Covid-19
}

\author{
Sinariati Putri Yani Pasaribu ${ }^{1 凶}$, Riris Debora Hutasoit ${ }^{2}$, Yeshi Naomi Sihombing $^{3}$, \\ Sri Ninta Tarigan ${ }^{4}$ \\ Universitas Prima Indonesia, Indonesia ${ }^{1,2,3}$ \\ E-mail : inayanipasaribu@gmail.com ${ }^{1}$, ririshutasoit318@ gmail.com ${ }^{2}$, yeshinaomi2001@ gmail.com ${ }^{3}$, \\ srinintatarigan@unprimdn.ac.id ${ }^{4}$
}

\begin{abstract}
Abstrak
Mempelajari bahasa Inggris sebagai bahasa Asing bukanlah hal yang mudah,terkhususbagi para siswa/I yang berasal dari beragam bahasa ibu. Salah satu faktor terbesar dalam memperoleh bahasa yaitu Vocaulary. Penelitian inibertujuan untuk mengatasi masalah siswa dalam memperkaya vocabulary guna meningkatkan kemampuan berbahasa Inggris mereka. Penelitian ini akan diaplikasikan dengan Penelitian Tindakan Kelas dimana penelitian tersebut dilakukan dikelas bahasa yang sedang mempelajari bahasa inggris melalui google Classroom. Adapun metode yang digunakan dalam penelitian ini adalah metode deskriptif kualitative metode dimana data akan dikumpulkan dengan observasi secara langsung secara tatap muka. Kemudian metode pengajaran vocabulari akan diaplikasikan dengan menggunakan metode flashcard selama 3 cycle . kemudian peneliti akan melakukan test terhadap siswa/I SMP disetiap cycle guna mendapatkan data. Adapun hasil penelitian menemukan bahwa media Flashcard sangan effective dalam pembelajaran vocabulary siswa.
\end{abstract}

Kata kunci: Peningkatan, Vocabulary siswa, Flashcard Media, Google Classroom

\section{Abstract}

Learning English as a foreign language in Indonesia is not easy, especially for students who came from various mother tongue. One of the biggest factors in acquiring the language is Vocabulary. This study aims to provide some solutions for Junior High school students to enhance their vocabulary skills to improve their English skills. It was applied a classroom Action Research where the researcher studied the English classroom during learning English Vocabulary in Google classroom. The method we have used in this research is descriptive qualitative with data collected through face-to-face observations. It was conducted through 3 cycles and was tested via Google Classroom with junior high school students for 3 CAR cycles. The results showed that flashcards media were very effective in enhancing students' vocabulary.

Keywords: Enhancing, Student's Vocabulary, Flashcard Media, Google Classroom

Copyright (c) 2022 Sinariati Putri Yani Pasaribu, Riris Debora Hutasoit, Yeshi Naomi Sihombing, Sri Ninta Tarigan

$\triangle$ Corresponding author:

Email : inayanipasaribu@gmail.com

DOI : https://doi.org/10.31004/edukatif.v4i1.1808

ISSN 2656-8063 (Media Cetak)

ISSN 2656-8071 (Media Online) 
228 Enhancing Student's Vocabulary by Using Flashcard Media Via Google Classroom During Covid-19Sinariati Putri Yani Pasaribu, Riris Debora Hutasoit, Yeshi Naomi Sihombing

DOI: https://doi.org/10.31004/edukatif.v4i1.1808

\section{INTRODUCTION}

English as it is often spoken is an international language and has many benefits to learn. Many companies with large salaries require "can speak English" of the many requirements they ask for and "can speak English" here not only able or smart regarding material or theory but also must be able to speak fluently or at least be able to express sentences common spoken in a conversation, it is certainly more fun if it is more fluent. In learning English, there are four skills that we must master, namely listening, speaking, reading, and writing. We will also find two essential components that support these four skills, they are vocabulary or words and grammar or sentence structure. In the early stages of learning English because vocabulary is easy to understand and learn by students because there are no rules or formulas that students need to know, such as when learning grammar, vocabulary is a supporter of the four skills and also grammar. Vocabulary is central to English language teaching. Without sufficient vocabulary, students cannot understand others or express their ideas (Michael Lessard, 2013)

Most people when traveling abroad bring a dictionary to help them communicate with other people compared to grammar books. This proves that the large vocabulary we have can help us communicate with other people. In the end, with mastery of vocabulary, students can master English easily, vocabulary mastery is a measure of a person's understanding of the vocabulary of a language and his ability to use that vocabulary both orally and in writing. When we listen to something in English with a collection of vocabulary that we understand, we can easily get the meaning of what we hear.

Through the explanation above, it can be concluded that vocabulary is the beginning to make it easier for us to understand and apply English in the world of education and communication. To enhance the vocabulary, learning must be done interactively, inspiring, fun, supported by the use of media that can motivate students to participate actively in learning. And the use of flashcard media is one of the media that allows the above, flashcard media is very affordable and even easy if you want to make your own. According to Arsyad (2011) said that "flashcards usually measuring $8 \times 12 \mathrm{~cm}$, or can be customized with the size of the class faced".

There are previous studies that use this Flashcard media to improve writing skills in Germany, and it is concluded that the learning media flashcards have a positive impact which is significant to skills write a simple essay in Germany students. And in other studies the use of flashcard media to improve students' English vocabulary skills in listening and speaking vocabulary subjects about animal names in class can be effective, this can be seen from the activities of teachers and students during the learning activities. With the use of flashcard media, it can make it easier for teachers to deliver material learning and for students to increase students' vocabulary and make learning is fun, and children are motivated to actively participate in activities learning so that positive interactions occur between teachers and students, students and students, students and students with learning media.

Most students feel they don't understand anything when learning English, it's hard to remember even a single word. This is where we start our research which can be considered basic with simple media, we rely on the brain's fast capture of images.

Based on previous research it was said that by using Flashcard Media students became more enthusiastic in learning English vocabulary, previous research did not include how researchers helped students in remembering vocabulary and a series of activities carried out by researchers in learning. In this study, the author includes activities during learning to enhance vocabulary, the writers also include a way to remember vocabulary in the long term, namely by making a few simple sentences from the vocabulary.

The impact of the Covid-19 pandemic has an impact on psychological conditions and changes in human behavior that are broader over a longer period. This also has an impact on the education system in Indonesia. Covid-19 has disrupted the face-to-face learning process. Therefore, it is necessary to find an online learning 
229 Enhancing Student's Vocabulary by Using Flashcard Media Via Google Classroom During Covid-19Sinariati Putri Yani Pasaribu, Riris Debora Hutasoit, Yeshi Naomi Sihombing

DOI: https://doi.org/10.31004/edukatif.v4i1.1808

solution as an answer to these problems, many media are already available to do this online learning such as the zoom application, google classroom, google meet, WhatsApp, and many more. in this study the author tries to use learning via google classroom, and to facilitate communication and discussion, the author also creates a group chat room in the WhatsApp application.

The main target of using Flashcard media to enhance vocabulary is junior high school students because there is a condition where English lessons are not taught in elementary schools but when they enter high school, students immediately learn about grammar. It's a bit unfortunate because many students have never even learned the basics of English.

\section{RESEARCH METHODS}

Kurt Lewin stated that CAR consists of several cycles, each cycle consisting of four steps, they are Planning, Action, Observation, and Reflection. Firstly, the researchers planned the activity of preparing operational steps to achieve the results that have been formulated in the strategy. Planning includes steps to determine what has to be done. Secondly, actioning the main activity in classroom action research and is followed by observation and reflection activities, this implementation can be said to be an implementation process of the teaching and learning process, this implementation leads to the process of teaching and learning activities in the classroom after designing and planning that is quite easy to convey material in a class. Thirdly, Observation is an activity carried out on a process or object by feeling and then understanding the knowledge of a phenomenon based on previously known knowledge and ideas, to obtain the information needed to continue research, this activity is expected to be useful for finding information about an object. Finally, Reflecting an activity of analysis and interpretation of all information obtained during Action activities. In this activity, we examine, see, and consider the results or impacts of the action activities. The subjects to be studied are students of SMPN 7 Medan in grades VIII-4, totaling 8 students, the school is located at Jl. H. Adam Malik no. 12, Kec. Medan Barat, Kota Medan, Sumatera Utara. Due to the pandemic Covid-19 situation, the research will be conducted online through Google Classroom.

The research procedure of this research consist of two cycles, there is no difference in activities in cycle I and II. It's just that the planning part is only carried out in cycle I. In the foremost action, The teacher prepares a lesson plan that will be implemented in improvement, namely the plan to enhance vocabulary using Flashcards. Then, Prepare a minimum of 20 Flashcards. Furthermore, The teacher determines the standard of completeness criteria with students who can remember all the vocabulary that has been given and can form it into a simple sentence. Then, Prepare observation sheets for colleagues to observe during the vocabulary improvement process colleagues record things found during the learning process both advantages and disadvantages to provide input after the completion of learning to improve learning in cycle II if needed. Afterward, Teachers carry out learning according to the Improvement Plan vocabulary that has been compiled in cycle I, with the following steps: activity steps include Open the lesson, Delivering learning objectives and providing apperception, Explain the activities that we will do by involving Flashcard, The teacher shows the card and explains the picture on the card, Help students memorize vocabulary by giving some example sentences, Repeating the vocabulary in the picture, Guiding students in making simple sentences from vocabulary in Flashcards, Provide evaluation, Making conclusions with students and finally Closing the lesson.

The next step Observation was made during learning, to find out whether students like to memorize vocabulary using Flashcards media, whether students' vocabulary can be improved with Flashcards media. In cycle I, students are still adapting to learning English which is more familiar, many students are still overwhelmed in memorizing vocabulary, especially to form it into a sentence. At the end of learning in cycle I, the teacher reflects, that students are still not familiar with Flashcards-based learning and students need time to adapt. draw necessary conclusions improvements made in the second cycle of learning. The data was 
230 Enhancing Student's Vocabulary by Using Flashcard Media Via Google Classroom During Covid-19Sinariati Putri Yani Pasaribu, Riris Debora Hutasoit, Yeshi Naomi Sihombing

DOI: https://doi.org/10.31004/edukatif.v4i1.1808

analyzed in quantitative data and described in qualitative data which was gained from observations made during English lessons, teaching is carried out by researchers with the permission of the class teacher and English exam results.

Direct observation is done by teaching English by researchers, during the lesson the researcher asks the meaning of the vocabulary listed in the material, and the Test Results are taken from the value of the English composing assignment and the previous semester's test scores.

\section{RESULT AND DISCUSSION}

This research has been completed by going through two cycles within $2 \times 40$ minutes. Below will be explained the results and discussion of the first and second cycles along with the test results for each cycle.

\section{Cycle I}

The first cycle of learning started at 08:50 a.m and closed at 09:30. In the first cycle, the teacher has explained how vocabulary enhancement will be carried out using Flashcard media. One of the researchers began to show the picture and asked the students to guess the picture, then the researcher would be referred to as the teacher. students guess in Indonesian and the teacher gave instructions to the students so they could guess the vocabulary in English, after that the teacher asked some students to make some simple sentences from the vocabulary, and so on until the last vocabulary. To find out whether students could remember vocabulary correctly, the teacher gave a test. Due to the limited time for face-to-face learning, the test was conducted through Google Classroom media. Previously students had been directed to enter online classes that had been created by the teacher. Students were given 30 minutes to do the test. The result found that the score of students' English Tests was not improved significantly, the researcher decided to take the second cycle.

\section{Cycle II}

In this second cycle research, the teacher taught vocabulary by continuing through the stages in the first cycle with the same material, and still giving online tests. The following are the test results from the second cycle. After Observations made by writers from the second cycle of research, students seem to be more familiar with flashcard media. Students are easier to remember vocabulary from flashcards and the improvement is much better, along with the test results from the second cycle of research. Based on the results of learning observations in cycle two, in general, the learning has been going well and is better than the previous learning. Learning in cycle two starts with planning the implementation of learning by using image media in the material for studying attitudes to realize unity in diversity at school and home.

\section{Discussion}

By taking advantage of students' strong memory of pictures, writers chose flashcard media as a medium to enhance students' vocabulary. Because with flashcard media students can quickly catch lessons with more enthusiasm in learning English. From our research, it was proven that learning while playing is very effective for students. Through the pictures contained in the flashcards shown by the writers when conducting research students were very enthusiastic to learn, they began to guess what was drawn and they were even excited to look up the word in English through a dictionary. When students started learning with enthusiasm, it is a good thing in the learning process. The teacher asked the students to repeat the words in the flashcards and made simple sentences to retain students' memories. So that's how flashcard media enhanced students' vocabulary. During the research, the writers observed that the student's response to the teacher who taught was very good. During learning the teacher got feedback from students in the form of responses such as answering when asked, being active when discussing, and asking if asked.

There will be interactions between students and the environment during the learning process. As a result, teachers and students not only interact in the learning process but also interact with other sources. For example, flashcard media. Learning, according to Hafidin, is the effort of a teacher or educator to organize, 
231 Enhancing Student's Vocabulary by Using Flashcard Media Via Google Classroom During Covid-19Sinariati Putri Yani Pasaribu, Riris Debora Hutasoit, Yeshi Naomi Sihombing

DOI: https://doi.org/10.31004/edukatif.v4i1.1808

construct, and develop appropriate teaching and learning atmosphere in the classroom. encouraging, stimulating, and challenging, as well as providing a sense of security and protection. arouse students' interest in participating in learning activities optimally. And the use of flashcard media in the learning system is very beneficial in the development of science, this flashcard media is very helpful for the teaching and learning system because it makes it easier for students to learn English, especially to enhance their vocabulary and with this flashcard media, it can improve the quality of education for the better and be more creative.

From the results of this discussion, the writers found that flashcard media was indeed effective in enhancing students' vocabulary. According to the opinion of some students who were the targets of this research, the use of flashcard media is very simple and easy to understand, the way of explanation is also very interesting because you can see directly on the picture, it is very helpful to add vocabulary words in English.

\section{CONCLUSION}

After doing research, the writers concluded that the use of Flashcard media is very effective in enhancing vocabulary through stages, 1 . teacher showed pictures 2. students guessed, 3. teacher gave instructions and asked students to answer in English 4. students looked for English from vocabulary in the dictionary 5. teacher repeated vocabulary with students aloud 6. teacher guided students to make some simple sentences, students could develop their vocabulary and even remembered it for a long time. As for this research, the writers humbly convey that our writing still has many shortcomings and may not have reached the standard target. From this, the writers learned that we as writers still need to expand our knowledge. We hope that this research can provide benefits to readers and can contribute to education in Indonesia.

\section{REFERENCES}

Anggreany, Femmy\& Saud, Syukur. (2017). Keefektifan Media Pembelajaran Flashcard dalam Keterampilan Menulis Karangan Sederhana Bahasa Jerman Siswa Kelas XI IPA SMA Negeri 9 Makassar. Eralingua: Jurnal Pendidikan Bahasa Asing Dan Sastra.

Arman A, (2019) Media Flashcard: Goresan Pena.

Aqib, Z \& Chotibuddin M. (2018) Teori Dan Aplikasi Penelitian Tindakan Kelas (PTK) : Deepublish Publisher.

Azabdaftari, Behrooz, Mozaheb, A. Mohammad. (2012). Comparing Vocabulary Learning Of EFL Learners By Using Two Different Strategies : Mobile Learning Vs. Flashcard. Iran : N/A.

Crimastianto, A.W Imanuel\&Maryanto, I.P Rahel. (2017). Penggunaan Media Flashcard Untuk Meningkatkan Pengenalan Bentuk Huruf Siswa Kelas Satu Pada Mata Pelajaran Bahasa Indonesia Di Sekolah ABC Manado. Pedagogia: Jurna IIlmu Pendidkan.

E. Clayson D. (2021), A Comprehensive Critique Of Student Evaluation Of Teaching : Routledge.

Endraswara, S. (201. Metodologi Penelitian Postmodernisme Sastra. Yogyakarta: Center for Academic Publishing ServicE.

Fauziah F \& Rinayanti M. (2020). Cara Praktis Menggunakan Google Classroom : Deepublish.

Gusty S, Nurmiati Nurmiati, Muliana Muliana, Sulaiman O.K, Ginantra N.LW.S.R, Manuhutu M.A, Sudarso A, Leuwol N V, Apriza Apriza, Sahabuddin A A, Hastuti P,Setianto A.Y,Metanfanuan T, Uktolseja L.J, Jamaludin Jamaludin, Gaspersz S, Karwanto Karwanto, Bungin E R, Warella S Y. (2020). Belajar Mandiri: Pembelajaran Daring Di Tengah Pandemi Covid 19 : Yayasan Kita Menulis.

Hotimah, Empit. (2010) Penggunaan Media Flashcard dalam Meningkatkan Kemampuan Siswa pada Pembelajaran Kosakata Bahasa Inggris Kelas II MI AR-Rochman Semarang Garut. Jurnal Pendidikan Universitas Garut.

Ilinawati I, Dharma V(2019). Improving Student's Vocabulary Through Songs. (JEES). 
232 Enhancing Student's Vocabulary by Using Flashcard Media Via Google Classroom During Covid-19Sinariati Putri Yani Pasaribu, Riris Debora Hutasoit, Yeshi Naomi Sihombing

DOI: https://doi.org/10.31004/edukatif.v4i1.1808

Jenkins A, (2015). A Roadmap For Evaluating Online Teaching.( ELearn).

Komachali, E. Maryam, Khodareza and Mohammadreza. (2012). The effect of using vocabulary flashcard on Iranian Pre-University students' vocabulary knowledge. Iran : N/A.

Lessard-Clouston M (2013) Word Lists for Vocabulary Learning and Teaching : ( The Catesol Journal).

Mortimore, C. (2020), Disciplinary Literacy And Explicit Vocabulary Teaching A Whole School : John Catt Educational.

Ozen B \& Mohammadzadeh B. (2012) Teaching Vocabulary Through Poetry In An EFL Classroom : Eric Clearinghouse

Pinandhito K, Martia D.Y \& Prasetya B (2020). How I Use Google Classroom As A Teacher And Student: CV Jejak.

Raco, R, J., \& Semiawan, Conny R. (2010). Metode Penelitian Kualitatif. Jakarta: PT Gramedia Widiasarana Indonesia.

Rosali E.S. (2020) Aktifitas Pembelajaran Daring Pada Masa Pandemic Covid-19 Di Jurusan Pendidikan Geografi Universitas Siliwangi Tasikmalaya: GEOSEE.

Sadikin A, \& Hamidah A. (2020). Pembelajaran Daring Ditengah Wabah Covid-19 : BIODIK.

Susanto A. (2017). The Teaching of Vocabulary: (Jurnal Kata). 